 \\ z Filologii Polskiej i Słowiańskiej
}

\section{Profesor Roman Laskowski}

(1936-2014)

21 czerwca 2014 roku po długiej i ciężkiej chorobie zmarł w Krakowie Profesor Roman Laskowski, jeden z najwybitniejszych polskich językoznawców polonista, bohemista, teoretyk języka i metodolog językoznawstwa.

Roman Laskowski urodził się 17 lutego 1936 roku w Komarnie niedaleko Lwowa. Jego ojciec zaraz po zajęciu wschodnich ziem Rzeczpospolitej przez wojska radzieckie został aresztowany przez NKWD. Do ojczyzny nigdy nie wrócił. Jego matka $\mathrm{z}$ trzema synami została wywieziona do Kazachstanu. Dzięki swojej niezłomności i heroicznej postawie udało się jej uratować synów, wydostać z ZSRR i osiąść w 1946 roku w Kietrzu Śląskim. Właśnie tam Roman Laskowski zdał egzamin maturalny w liceum ogólnokształcącym, by w roku akademickim 1954/1955 rozpocząć studia slawistyczne na Uniwersytecie Jagiellońskim, które ukończył w roku 1959.

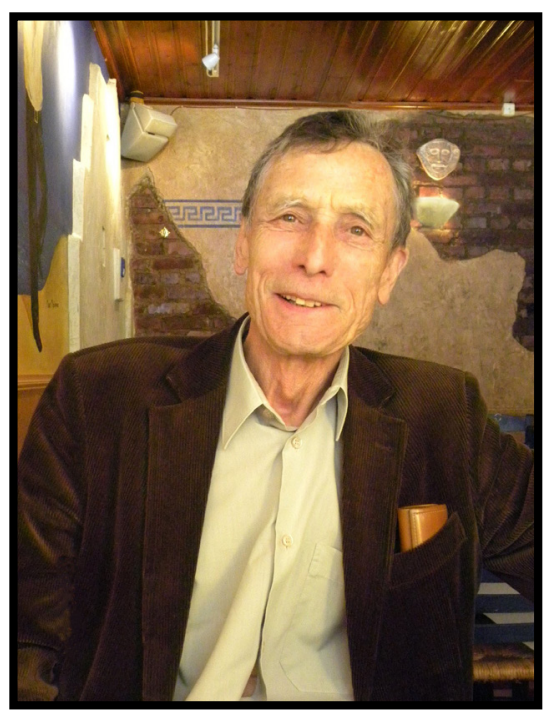

Profesor Roman Laskowski w styczniu 2011 roku w Göteborgu (fot. ze zbiorów rodzinnych)

This is an Open Access article distributed under the terms of the Creative Commons Attribution 3.0 PL License (creativecommons.org/licenses/by/3.0/pl/), which permits redistribution, commercial and non-commercial, provided that the article is properly cited. (C) The Author(s) 2014.

Publisher: Institute of Slavic Studies, PAS \& The Slavic Foundation

[Wydawca: Instytut Slawistyki PAN \& Fundacja Slawistyczna] 
Pierwszą swą pracę naukową podjął w Śląskim Instytucie Naukowym w Katowicach, a następnie w Zakładzie Słowianoznawstwa Polskiej Akademii Nauk. W tym czasie był członkiem zespołu przygotowującego pod kierunkiem prof. Alfreda Zaręby Atlas Językowy Śląska, a także pisał swą rozprawę doktorską na temat derywacji rzeczowników w dialektach laskich. Stopień doktora uzyskał w roku 1969 na Uniwersytecie Jagiellońskim, tam też się habilitował w roku 1974 na podstawie rozprawy zatytułowanej Studia nad morfonologia współczesnego języka polskiego. Był już wtedy bowiem pracownikiem powstałego rok wcześniej Instytutu Języka Polskiego Polskiej Akademii Nauk. Z tą placówką związany był bardzo mocno całe swoje późniejsze życie, choć pracował także na Uniwersytecie w Göteborgu (w latach 1985-2000), na Uniwersytecie Jagiellońskim (w latach 2001-2007) i w Wyższej Szkole Psychologii Społecznej (w latach 2008-2012).

W Instytucie Języka Polskiego PAN rozpoczął swoje poszukiwania językoznawcze od analizowania tekstów dawnych wspólnie ze zmarłym kilka tygodni wcześniej prof. Wacławem Twardzikiem. Współpracę tę Roman Laskowski bardzo sobie cenił - wracał do niej wielokrotnie w następnych latach, mimo że miał już wtedy bardzo precyzyjnie wyrysowaną swoją własną teorię lingwistyczną, która bardziej skupiała się na wyjaśnianiu zjawisk gramatycznych współczesnego języka polskiego, w szczególności jego morfologii.

W encyklopedycznych hasłach poświęconych Romanowi Laskowskiemu powtarzana jest teza, że był on pionierem i prekursorem fonologii generatywnej. Istotnie - jego książka pt. Studia nad morfonologia współczesnego języka polskiego (Wrocław: Zakład Narodowy im. Ossolińskich, 1975) była wielokrotnie wykorzystywana w pracach $\mathrm{z}$ zakresu fonologii generatywnej. Koncepcja morfonologii zawarta $w$ tej pracy z całą pewnością nawiązuje jednak do założeń morfonologii wypracowanych w Praskim Kole Strukturalnym przede wszystkim przez N. Trubieckiego, który wprowadził pojęcie morfonemu rozumianego jako wyobrażenie wszystkich członów alternacji. Fakt zaś, że zbudowana na tych fundamentach przez Romana Laskowskiego pełna morfonologia języka polskiego zyskała uznanie w powstającej właśnie fonologii generatywnej, jest łatwy do wytłumaczenia. Wystarczy bowiem przypomnieć, że na kształt komponentu fonologicznego i morfonologicznego w modelu generatywnym wielki wpływ wywarł Roman Jakobson.

W przekonaniu niżej podpisanego największym osiągnięciem Romana Laskowskiego było stworzenie oryginalnej, rozbudowanej i koherentnej teorii morfologii, na której bazuje opis podsystemu morfologicznego języka 
polskiego zawarty m. in. w podręczniku akademickim Gramatyka współczesnego języka polskiego. Morfologia, pod red. Renaty Grzegorczykowej, Romana Laskowskiego i Henryka Wróbla (wyd. 1. Warszawa: PWN, 1984). Teoria morfologii wypracowana przez Romana Laskowskiego również nawiązuje do strukturalizmu praskiego, ale w punkcie wyjścia także do amerykańskiego dystrybucjonizmu. Szczególnie wyraźnie widać to w klasyfikacji jednostek leksykalnych - jej bowiem podstawą jest dystrybucja składniowa. Za najbardziej misterną konstrukcję intelektualną w morfologii Romana Laskowskiego może uchodzić schematyczne przedstawienie pomostów pomiędzy rodzajem gramatycznym rzeczowników a rodzajem gramatycznym czasowników, przymiotników i liczebników. Zestawienie to mieści się na dwóch stronach druku, żeby wszakże mogło zostać wykonane, jego autor musiał przeanalizować tysiące syntaktycznych kontekstów diagnostycznych.

Bardzo ważną książką Romana Laskowskiego jest również wydana w 2009 roku praca zatytułowana Język w zagrożeniu. Przyswajanie języka polskiego w warunkach polsko-szwedzkiego bilingwizmu (Kraków: Universitas). Jej podstawą materiałową były dane zebrane przez Uczonego podczas wieloletnich obserwacji tekstów dzieci polskich emigrantów w Szwecji. Autor broni w niej bardzo istotnej ze społecznego punktu widzenia tezy dotyczącej wartości dwujęzyczności. Oprócz naświetlenia niezwykle interesujących z punktu widzenia teorii morfologii typowych, aczkolwiek nie mieszczących się w standardowej polszczyźnie, konstrukcji tworzonych przez dzieci polskich emigrantów książka zawiera wiele doskonale uzasadnionych wskazówek dla rodziców i nauczycieli.

Profesor Roman Laskowski zawsze myślał i działał prospołecznie. W latach osiemdziesiątych niezwykle czynnie włączył się w ruch solidarnościowy. Był zastępcą przewodniczącego Komisji Zakładowej „Solidarności” Oddziału PAN w Krakowie oraz wiceprzewodniczącym Ogólnopolskiej Komisji Porozumiewawczej NSZZ „Solidarność” PAN. W stanie wojennym aresztowany, zaraz po odzyskaniu wolności włączył się $\mathrm{w}$ prace struktur podziemnych związku. Był jednym z założycieli „Biuletynu Małopolskiego”, który stał się organem prasowym Regionalnej Komisji Wykonawczej Regionu Małopolska. W czerwcu 1982 stworzył zespół programowy RKW, kierował następnie tzw. Grupą Opinii i Analiz. Wielokrotnie nękany przez służby PRL, zmuszony został do wyjazdu do Szwecji. Będąc kierownikiem slawistyki na Uniwersytecie w Göteborgu, organizował cykliczne sympozja i konferencje, w których uczestniczyło wielu ludzi kultury i nauki nie tylko z Polski, ale też z innych 
krajów obozu komunistycznego. Już po powrocie do wolnej Polski starał się stawić czoła zagrożeniom rodzącej się demokracji. Był m. in. współzałożycielem i jednym z liderów Ruchu na Rzecz Demokracji.

Za swe dokonania naukowe i działalność społeczną Profesor Roman Laskowski został odznaczony Krzyżem Kawalerskim Orderu Odrodzenia Polski. Pełnił też zaszczytne funkcje w gremiach i stowarzyszeniach naukowych. Był członkiem Międzynarodowej Komisji Słowotwórstwa Języków Słowiańskich, Międzynarodowej Komisji Budowy Gramatycznej Języków Słowiańskich i Międzynarodowej Komisji Fonetyki i Fonologii Języków Słowiańskich działających przy Międzynarodowym Komitecie Slawistów. W 1986 został członkiem Królewskiego Towarzystwa Sztuki i Nauki w Göteborgu. Od 1990 był członkiem-korespondentem, a od 2001 członkiem czynnym Wydziału I Filologicznego Polskiej_Akademii Umiejętności. Należał do Czeskiego Towarzystwa Językoznawczego, po pięćdziesięcioletnim stażu w Polskim Towarzystwie Językoznawczym w roku 2010 został jego członkiem honorowym. Wielokrotnie był wybierany do Komitetu Słowianoznawstwa i Komitetu Językoznawstwa PAN. Był redaktorem naczelnym „Biuletynu Polskiego Towarzystwa Językoznawczego” i „Studies in Polish Linguistics”.

\section{Ireneusz Bobrowski}

Keywords: obituary notice; Roman Laskowski (1936-2014); Poland; Slavic studies; linguistics; Polish language; generative phonology; morphology; morphonology

Słowa kluczowe: nekrolog; Roman Laskowski (1936-2014); Polska; slawistyka; językoznawstwo; język polski; fonologia generatywna; morfologia; morfonologia 